\title{
Sustainable Information Development Practices and Societal Transformation in Kenya
}

Elisha Ondieki Makori, University of Nairobi, Kenya

iD https://orcid.org/0000-0003-1966-3253

\begin{abstract}
This paper demonstrates the impact of the information discipline and profession in transforming and changing the lives of people through sustainable development practices and policies. Quantitative and qualitative research design collected data from information academicians and professionals. Questionnaires and interviews were used to obtain primary data while document analysis and related sources provided secondary information. Decent work and economic growth are the leading and relevant rudimentary goals of sustainable development practices that provide not only perfect employment and wealth creation opportunities but also the fundamental denominator to poverty eradication, food security, quality education, good health and well-being, as well as clean water and sanitation. Post-implementation strategies for building sustainable development practices should connect the social, economic, and political aspects of people with practical policies.
\end{abstract}

\section{KEYWORDS}

Information Academicians, Information and Development, Information Organizations, Information Professionals, Information Science, Kenya, Sustainable Development Goals

\section{INTRODUCTION AND BACKGROUND INFORMATION}

Digital innovations, technological impact, big data and information explosion, transformation and change for societal development are factors that have profound implications on human life across the globe. Historically, people on the African continent have experienced numerous notable challenges including underdevelopment, poverty, diseases, ignorance, wars, socio-economic inequalities, political instability and human rights abuses. In September 2015, a new strategy of sustainable development goals (SDGs) or global agendas to promote socio-economic growth and prosperity was adopted worldwide. Sustainable development goals promote socio-economic growth through tangible policies and programs, and information organizations, academicians and professionals are indeed important in the new dispensation. Equally, information professionals are involved in almost every field of endeavour imaginable in the society, and therefore, crucial in the development process. In sustainable development, the critical role and performance of the information profession in human life is fundamental and important in the society. 
The evolution and foundation of information science is grounded in the philosophy of managing data, information, knowledge, technology and people. Information science promotes social, political and economic aspects of humanity in the society. Access to information (Goal 16) promotes peaceful and inclusive societies for sustainable development. It also provides access to justice and builds effective, accountable and inclusive institutions at all levels (International Federation of Library Associations and Institutions, 2015). Increasing access to information and knowledge across society through the availability of information and communications technologies (ICTs) supports sustainable development and improves the lives of people, adds the author. According to the Lyon Declaration on Access to Information and Development, public access to information enables people to make informed decisions that support societies. Communities that have access to timely and relevant information are better positioned to eradicate poverty and inequality, improve agriculture, provide quality education, and support health, culture, research and innovation of the people. Information science trains and develops human resources that are fundamental in management of data, information, knowledge, technology and people.

\section{STATEMENT OF THE PROBLEM}

Modern perspectives of societal transformation and economic growth and prosperity require rudimentary elements of sustainable development goals that need rethinking, partnership and participation of people, professionals, organizations and communities. Sustainable development goals and targets offer new opportunities to address societal issues because many poor people need economic prosperity and social inclusion. African countries have been affected by underdevelopment and interdependence of growth practices characterized by extreme poverty, ignorance and health problems due to social inequalities, poor economic policies and solutions as well as endless political wars and conflicts. Despite the adoption of the initial millennium development goals (MDGs), poverty levels, inadequate food, lack of access to clean drinking water and sanitation, and inequalities have continued to dominate and affect human life. The sustainable development goals deal with information, knowledge, technology and people that have neither local limitations nor geopolitics, although research on this novel strategy in the information discipline and profession is new and emerging. Leveraging the rethinking of information science in sustaining societal transformation in rural communities that normally form the largest segment of the population affected by underdevelopment, poverty and diseases is fundamental in the modern digital economy and knowledge society.

The path to sustainable development practices includes quality research and educational programs (Siobhan, 2014), information, knowledge, and use of information communication technologies as indispensable tools for transforming economies and societies (Aida, 2016), and incorporating citizens in the production of relevant information useful in high efficiency decision situations (Russell et al, 2010). African institutions and organizations have recognized the crucial role of the information profession in development, made notable good policies and practices that support the industry through the integration of information technology in the curriculum, digital information systems (digitization, institutional repositories, social media, and widespread use of internet) with fundamental rights to information (EBSCO Report, 2012), although research linking sustainable development and information science is limited. While the United Nations recognizes the importance of information for sustainable development, there has been minimal progress made in linking sustainable development goals with information, knowledge and technology, and therefore, very little research has been devoted towards the strategic role of library and information science in the larger civilization project of sustainable development (Nolin, 2010). This research therefore explores practical sustainable information development practices where strategic insights from academic institutions, information organizations and information professionals were critically analyzed and presented. 


\section{PURPOSE AND OBJECTIVES OF THE STUDY}

The purpose of this study is to demonstrate the impact of the information discipline and profession in transforming and changing the life of people through sustainable development practices and policies. The objectives are to:

i. Examine relevant goals of sustainable information development practices applied in transforming societies;

ii. Determine practical sustainable development approaches used in bringing societal transformation and change;

iii. Demonstrate information methods applied in fostering environmental protection and sustainability;

iv. Determine appropriate strategies for attaining sustainable information development policies and practices.

\section{Research Questions}

i. What relevant goals of sustainable information development are important in transforming societies?

ii. Which practical sustainable development approaches are used to bring societal transformation and change?

iii. What information methods are applied in fostering environmental protection and sustainability?

iv. Which are the appropriate strategies for attaining sustainable information development policies and practices?

\section{LITERATURE REVIEW}

\section{Knowledge and Digital Economy}

Information science has played fundamental roles insofar as the transition into the modern knowledge society is concerned. In 1960, Peter Drucker noted that, in the knowledge economy of both present and future generations, the basic and fundamental economic resource is not capital, natural resources or labor but knowledge that transforms, informs and creates wealth for humanity and society (Wartzman, 2014). After 50 years, that fundamental philosophy is a true reflection of the knowledge society and reminder of the ideals of the founders of information science whose impetus for development is as old as mankind. In the $21^{\text {st }}$ century, the evolution of knowledge explosion and unabated exponential growth of information in all aspects of human life is evident with the immediate consequence to combat the problem. Rapid development of information communication technology being witnessed in the knowledge society is one such initiative to combat the problem.

Technology is not only the core aspect of the discipline and profession of information science, but it also influences all aspects of the modern knowledge society. In the broader sense, technology has transformed the information society to the knowledge society, knowledge age, knowledge economy, digital society, and digital economy. Knowledge and skills in information communication technology are critical component in the education and training of information science graduates (Al-Daihani, 2011). The knowledge economy has also made significant strides through the open source software movement that has been well adopted and used in Britain, France and Germany. In Africa, countries such as South Africa, Botswana, Nigeria and Kenya have made great progress towards the adoption and utilization of open source software programs in management and operations of government ministries, departments and agencies (MDAs) and private organizations. Widespread use of Koha in Australian special libraries and related agencies indicates that the open source movement has enabled many information establishments to greatly enhance services to remote users (Keast, 2011). Public 
and private organizations in Kenya have initiated numerous technological programs that handle and support information and knowledge management practices.

\section{Information Science Program}

The development of information science is founded on the principles of a knowledge society that fundamentally depends on technological systems and solutions for socio-economic transformation. High technological solutions, massive information digitization, social computing and media systems are facilitating new intensity in the application and utilization of knowledge for economic development and growth in the society. The profession has evolved over the past 60 years as a scientific and professional discipline that deals with management of data, information, knowledge, technology and people in the society. Information science brings together faculty, students and researchers who share the interest in combining computer science with the social sciences of how people and society interact with information (Cornel University, 2010).

Information science is the multidisciplinary field of specialization that integrates computer science, cognitive science, social science and communication science, although initially the development was grounded in the invention of computers (1940s), electronic information systems and online information retrieval solutions (McGonigle \& Kathleen n.d, \& Baruchson-Arbib, 2007). In the modern academic practices, the anticipation of the birth of information science in imparting knowledge management, taxonomies, social computing and informatics, social media systems, digital and electronic information systems, records and information governance, enterprise information systems and artificial intelligence is quite evident in curricula. Organizations have become intensely aware of the fact that information and knowledge are potent resources that must be cultivated and honed to achieve desired needs and goals, add the authors. In a nutshell, information science is the discipline (interdisciplinary and multidisciplinary field) and profession that brings knowledge, information, technology and people together for sustainable development and growth.

In the United States, the Congress and other government agencies approved during the 1950's and 1960's a number of strategic programmes that funded large scale efforts to control information explosion, first in science and technology and then in all other fields. Public and private enterprises competed in developing practical systems for effective online information retrieval systems until in the early 1970s when commercial online services appeared. These programs and efforts were responsible for the development and transition from pre-industrial to industrial and post-industrial societies, and eventually to the knowledge society and digital economy. The United States played a prominent role in the development of information science just as in computer science, although the invention of the subject and issues of information explosion are not only for the American society in nature but international or global concerns. Information science addresses issues of multidisciplinary and cultural diversity where humanity and society are united against the common enemies of underdevelopment, poverty and diseases without political, geographical boundaries or racial discrimination.

\section{Information Science in Africa and Kenya}

African countries that lead in library and information science education and training include South Africa, Nigeria and Kenya. In the East African Community, Kenya has the largest university learning systems including the field of library and information science whose monumental growth is as a result of the increasing number of students wanting to acquire higher education and training. There are 53 public and private universities with affiliate colleges or campuses within the country or in the East African region (Commission for University Education, 2019). The number of higher education and training institutions in Kenya rose from six public universities in 2003 to 53 in 2017. As a result, the number of university students and the admission for education and training opportunities in both public and private institutions has increased tremendously. Due to the increasing quest for knowledge, the government plans to establish the Open University to expand and increase education and training opportunities both nationally and locally. 
Information science programs are offered in public universities of Nairobi, Moi, Kenyatta and Egerton as the leading and oldest institutions as well as private ones such as Catholic University of Eastern Africa and Kenya Methodist University. Information from the websites indicates that most of the universities offer academic programs at bachelors, masters' and doctorate levels (University of Nairobi, 2019; Kenyatta University, 2019; Moi University, 2019). Moi University has bachelors, postgraduate and doctorate studies in information sciences (Makori, 2013) while University of Nairobi offers bachelor of information science, master of information science, doctor of philosophy in information science and diploma in information science. Historically, studies by Rosenberg formed the basis for the establishment of the school of information sciences at Moi University in 1988. Rapid expansion of higher education has led to the increased enrollment of students in public universities with significant numbers going for vacancies in private and foreign institutions. Consequently, students pursuing library and information science programs are increasingly growing due to the rapid expansion of higher education and training in public and private institutions.

\section{Sustainable Development Goals}

Development is a broad concept that includes the interdependence aspects of human life in social, economic and political spheres. Political and economic development is fundamental in social transformation. Economic growth may bring material gain to the people, but development is much about enrichment of the lives of all the people in the society (Dale, 2012). Sustainable development is the new strategy and catalyst for transformation and change through interdependence and participatory practices in people, communities and societies. The goals are globally or universally accepted practices that are intertwined and interrelated to transform humanity and societies through equitable solutions. The global strategic goals that promote economic growth and environmental protection were adopted at the United Nations Summit in New York, in September, 2015 (United Nations Development Programme, 2016). The primary aim of the goals is to ensure quality of life and end poverty, fight hunger, inequality and injustice, tackle climate and the environment, improve access to health and education as well as build strong institutions and partnerships. The global agendas consist of 17 goals with 169 targets that world governments need to cascade into own national development plans for economic benefits, social inclusion and environmental friendliness (see Figure 1) (United Nations Development Programme, 2016 \& Jeffrey, 2012). Fundamentally, the goals include no poverty, zero hunger, good health and well-being, quality education, gender equality, clean water and sanitation, affordable and clean energy, decent work and economic growth, industry, innovation and infrastructure, reduced inequalities, sustainable cities and communities, responsible consumption and production, climate action, life below water, life on land, peace, justice and strong institutions, and partnerships. The strategies were developed based on the recommendations of the initial millennium development goals adopted in 2000, and whose main aim was to eliminate poverty, hunger, disease, gender inequality, and promote access to water and sanitation. Despite the huge success of the MDGs, the indignity of poverty around the globe has not ended but rather increased tremendously.

Sustainable development goals have quickly gained ground because of the growing desire to improve the quality of life for all people in all countries in the entire world. The strategies target mainly poor countries from which the rich ones add their solidarity and assistance through finances and technology (Jeffrey, 2012). The approach embraces the concept of triple bottom line approach to human well-being, where world governments and societies acknowledge the need for combinations of economic development, environmental sustainability and social inclusion, although the specific objectives differ globally, between and within countries, adds the author. There is need for individuals, communities, institutions, organizations and countries to take initiatives and responsibilities in transforming and changing societies, in order to constantly improve and sustain better life and future posterity. Reports from county governments indicate that, there are both good practices and challenges in the policies that enable countries to achieve co-benefits across sectors such as water, energy and food security (Kevin et al, 2014). World governments and the United Nations are taking this issue 

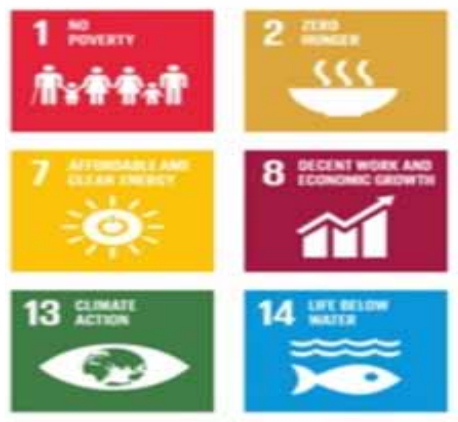

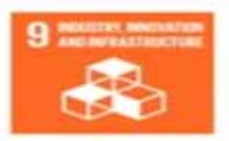

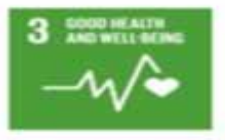
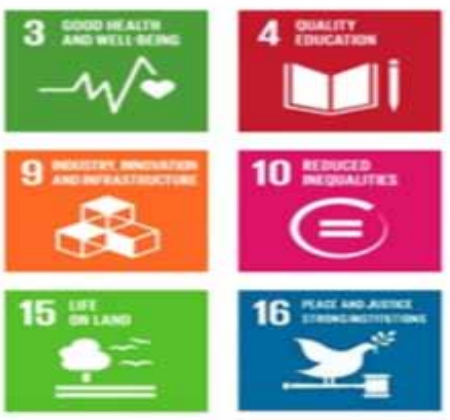
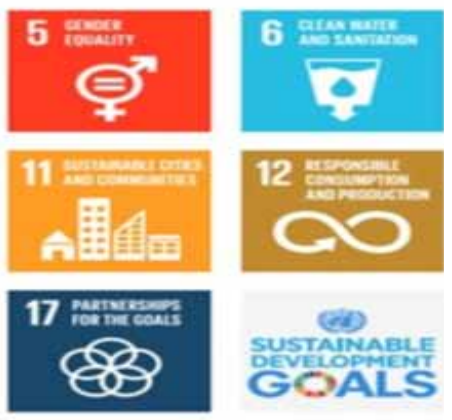

(C)

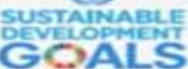

seriously as illustrated by the need to cascade sustainable development practices that not only transform societies but also promote and support initiatives. The global goals address multiple concerns that have constantly affected humanity and societal development practices since immemorial times.

\section{Climate and Environment Management}

Fundamentally, there is need to protect the planet and environment from pollution, accumulation and distribution of toxic wastes, destruction of forests and soil, and greenhouse emissions. Consequently, climate and environmental change due to pollution, desertification and disasters resulting to absolute poverty is among the concerns of the sustainable development goals that not only continue to affect organizations and countries but also need to be addressed in order to promote decent human life. Climate change provides the fundamental right to clean, healthy and protected environment to all people and for future posterity. There are blatant truths, and efforts taken to address the adversarial effects of climate change and environment from human activities that have constantly violated and exploited the planet without protection (United Nations Development Programme, 2016). First, there is no country in the world that is not seeing first-hand the drastic effects of climate change. Second, greenhouse gas emissions continue to rise tremendously since the 1990s. Finally, global warming is causing long-lasting changes to the climate system, which threatens irreversible consequences if appropriate action is not taken. In addressing the climate change, collective responsibility from all partners and stakeholders is essential if meaningful sustainable development approaches can be implemented, monitored and evaluated in protecting the environment.

Within the Kenyan context, the enactment of the Environmental Management and Coordination Act No. 8 of 1999 and the Environment and Land Court Act No. 11 of 2011 in the 2010 constitution guarantees the attainment of sustainable development goals (Constitution of Kenya, 2010). First, this achievement ensures the conservation and protection of the ecosystem's carrying capacity, and full enjoyment of the fruits of sustainable development by the future generations. Second, longterm measures in conserving environmental and natural resources must be taken in order to achieve the goals. Third, the significance of sustainable development is underscored more when viewed in the perspective of the constitution, in whose provision the state is held accountable to ensure sustainable exploitation, management, utilization and conservation of natural resources and environment as well as ensure equitable sharing of the accruing benefits. In this regard, the constitution assumes an 
ecological perspective to sustainable development which protects the environment both for ecological reasons and satisfaction of human needs.

\section{Sustainable Information Development and Societal Transformation}

\section{Economic Growth, Wealth Creation and Employment Opportunities}

Information science provides massive employment opportunities in various sectors of the economy. Notable opportunities are available in public and private academic and research institutions where library and information systems manage knowledge to support research, teaching, learning and community service. Information departments and related units normally offer the single biggest job opportunities for information professionals and academicians as lecturers, researchers, librarians, information and knowledge managers and record information managers. The library and information systems also provide students with attachment opportunities to acquire employment skills and competencies in the workplace. In addition, the national government and county governments have increased information science education and training opportunities through expansion and employment of records, information, knowledge, and technology professionals in rural and urban settings. In order to enhance information governance at national government and county governments, financial management practices and operations in public participation are normally required to promote accountability, transparency and integrity. Most importantly, the library and information systems provide information to the public through websites, information portals, libraries, information and documentation centers, digital and mobile apps, and social media. In conjunction with the national government, most of the county governments have universities while those without are being helped to establish them. As a result of this development, there is increased awareness and desire for students wanting to pursue information science programmes.

The information industry has also witnessed tremendous growth of library and information systems in government ministries, departments and agencies, state corporations and institutions. Public knowledge organizations employ many information professionals and academicians. Corporate information systems also exist in state agencies such as the Central Bank of Kenya, the Kenya Revenue Authority, the United Nations Environmental Programme, the Kenya Bureau of Standards, the Kenya Institute of Education, the National Museum, the Department of Mines and Geology, and media houses (Nation Media, Citizen and Kenya Broadcasting Corporation). Private information organizations and faith based institutions offer numerous employment opportunities. In order to expand and address the increasing nature of knowledge that depend upon technological solutions, corporate information systems provide social computing and internet services to the clients or customers. The Kenya National Library Services (KNLS) manages the national library and information services that include community based systems and promotional initiatives through camel library in Northern Kenya, tent reading and bus mobile services. The Kenya National Archives and Documentation Service (KNADS) promotes records and information services in digital or electronic government reports, newspapers, rare collections and sessional papers to support historical, sociological and cultural aspects.

Agriculture is the backbone of development activities in many developing countries. The national government reformed the agricultural research systems and established the Kenya Agricultural and Livestock Research Organization (KALRO) made up of 15 semi-autonomous institutes including the Dairy Research Institute, the Food Crops Research Institute, the Tea Research Institute and the Sugar Research Institute (Kenya Agricultural and Livestock Research Organization, 2016). The organizations and affiliated agencies form the largest network of agricultural information and communication systems in the country. International agricultural organizations also have library information systems that provide the much needed knowledge. Agricultural information systems provide knowledge, resources and technology, and disseminate research findings and publications. Legal information systems have expanded reasonably well since Kenya attained independence. Large libraries, information centers, and records and documentation systems have been developed in academic law institutions in universities of Nairobi, Moi, Kenyatta and Kisii, and the Kenya School of Law, in addition to private legal 
organizations. The Parliament and Senate have information departments that normally provide research and information services, although the collection consists of legal and administrative documents, general newspapers and magazines, and parliamentary proceedings. The Supreme Court, High Court and Court of Appeal have library and information systems that provide legal information services. Health education and training programs in academic and research institutions is another fundamental area where sustainable information development practices and the contribution of the information profession are being felt. Health information systems or informatics in public universities of Nairobi, Moi and Kenyatta, and other private institutions provide education and training opportunities for information science professionals.

\section{Rural and Community Development}

In the knowledge economy, the role of information science in rural and community development cannot be underestimated because knowledge and technology have become supportive assets for any socio-economic growth. Development programs in rural communities can only be achieved if the citizens have access to necessary, timely and relevant knowledge in order to enable people make informed decisions for economic growth and prosperity. In quoting Nyerere's article, Kamba (2009) argues that, while other countries in the world aim to reach the moon, we must aim for the time being at any rate to reach the villages by providing them with necessary information. Therefore, information science if well-articulated eradicates ignorance and gives enlightenment on how to achieve economic, educational, social, political and cultural objectives towards the development of the entire community. Therefore, handling of data, information and knowledge to support socio-economic plans and decisions in industries, organizations and homes depend upon digital innovations and technologies. Digital technologies bring massive and new opportunities and initiatives that promote development in rural communities.

Societal development needs are satisfied through numerous initiatives that require information, knowledge and technology. Development goals and practices in education, policy formulation, research and learning in public and private organizations require information, knowledge and technology. Access to necessary and relevant information addresses major problems that hinder rural community development and economic growth. With electronic money transfer, internet banking, mobile banking, internet mobile and social media, the population, including farmers and the business community, are well informed and able to respond appropriately to changes in the market. This provides effective means of sharing information and strengthening of social networking where people continue to develop using the knowledge acquired and disseminated. In this digital economy, Knowledge is conceived as an important human capital asset that contributes immensely towards development in the society. Knowledge provides the mainstay for socio-economic development, foundation for innovations, resources for informed citizenry, and the key commodity for the progress of any society. Information, knowledge and technology are increasingly becoming the key drivers for socio-economic development worldwide (Dzidonu, 2010).

\section{Green Information Movement}

Information organizations are taking appropriate measures to protect the environment from pollution, degradation, destruction and depletion through the Green Library Movement that began with the Talloires Declaration of 1990, and the triple bottom line of 1994. The declaration stresses on the need and commitment toward environmental sustainability in higher education and learning. In particular, urgent action is needed to reverse environmental problems and create an equitable and sustainable future for all humankind (William, 2013). Accordingly, universities have major roles in ecological restoration and adoption of environmentally sound industrial and agricultural technologies, debunks the author. Policy makers and leaders in universities have the responsibility to make sustainable decisions and mobilize internal and external resources in order to ensure that institutions respond to the environmental challenges that hinder people decent and quality life. Libraries and information 
professionals, as part of the university family and community, can support sustainable development by building environmental collections, providing environmental information, and promoting environmental literacy that leads to practical solutions (Jankowska, 2010).

Information organizations have embraced the concept and element of sustainability of going green through knowledge and practices that promote environmentally friendly and ecologically responsible decisions and lifestyles (Serap \& Joumana, 2014). Information professionals have taken more proactive roles in "green" practices and sustainable environmental solutions in public and academic libraries (Jankowska, 2010). Evolution of modern libraries is closely related to the development of modernity in western societies due to change of social life, growing importance of reading, information and knowledge, ideas of enlightenment, democracy and tolerance as well as open society (Dahlkild, 2011). Modern library buildings coupled with the need for adequate space in academic institutions have helped to advance the green information movement. Academic libraries need to adopt and implement sustainable green practices that promote and protect the environment. Information literacy provides fundamental knowledge and competency that helps to sustain and protect the environment for the betterment of humanity and society. A fundamental aspect of information literacy is to produce university graduates who are not only environmentally literate but also experts in environmental management, sustainable economic development, population and related fields (William, 2014). Green marketing and promotion approaches are exemplified through branded campaigns and programs like tree planting.

Educational institutions, universities and other organizations are rapidly building modern green information centers with designs and structures that appeal to the digital clients of the knowledge society and digital economy - millennials. Most important, the modern green temples of knowledge support the vision of teaching, learning and research environment suited for the benefit of the present and future generations - University of Nairobi, Kenyatta University, Catholic University of Eastern Africa and United States International University. Modern library and information systems normally place greater emphasis on green information systems through:

- Highly technological mediated systems, computing solutions, digital information and multimedia applications for social interaction and collaboration;

- Sharing information and communication with the clients using digital media platforms;

- Digital institutional repositories for online publishing and utilization of knowledge and findings;

- Interactive websites that encourage online discussion and communication with the clients;

- The Internet of Things that provides hyperconnectivity and social computing platforms for online information and communication.

\section{Community and Environment Protection}

One of the requirements of academic organizations is to pay back to the society through community services that protect the environment. Academic and information organizations express this cardinal role through corporate social responsibilities, where staff and clients engage in initiatives and programs that aim to cushion and assist the poor and less privileged in the community and society. Information professionals and academicians have made fundamental contributions in many community based programs leading to conservation of the environment through cleaning activities, tree planting sessions, contributions in form of materials (foods, clothes and books), assisting the vulnerable, and establishing information centers among the disadvantaged and marginalized groups. In addition, the professionals engage in sustainable development projects through funding raising activities in respective organizations and institutions. 


\section{Education and Training}

Higher education and learning offer equal training opportunities for all men and women with relevant qualifications, although youths and adults with disabilities and marginalized communities are given special preference in admissions. The information science curriculum provides quality education and training opportunities that underpins the aspirations of the modern learning and knowledge environment. Information science graduates are highly employable in various sectors of the economy nationally, regionally and internationally. "The constantly evolving employment situation in Africa means that graduates can no longer expect to be employed in just one sector throughout their professional life. The graduates need to be provided with skills to adapt to different situations in the job market. Students need to be aware that the job market operates in an increasingly globalized world" (Mohamedbhai, 2013). The information science education must match the needs of the labor market with employment opportunities. Information literacy skills facilitated by information professionals and academicians are effectively offered in educational institutions and organizations. Similarly, information professionals and academicians normally conduct studies that address issues that affect people and the society. Illiteracy levels are not only prevalent but also the chief cause of underdevelopment, ignorance and diseases in most parts of the country especially rural areas and shanty slums in urban centers.

\section{Gender Equality}

In order to achieve rapid development, address health issues, promote business, enhance equity, and address human rights abuses among women, children and vulnerable groups in rural areas and shanty urban slums, there is need to empower women through information, knowledge and technology. The universal declaration of human rights and the 2010 constitution advocate for affirmative action and approaches to promote gender balance at national and county governments as well as affiliated institutions and communities. Gender equality ensures that women and vulnerable groups in organizations, communities and societies are given opportunities without any bias and discrimination. Most important, information professionals have been elected and nominated to parliament, senate and county assemblies. Empowering women in rural and urban settings is the root cause of socioeconomic development and the fight against poverty, diseases and ignorance. Women manage business organizations that promote sharing and exchange of information and communication as well as lead and participate in various development activities in schools, churches, village committees and communities.

\section{Information Industry, Innovation and Infrastructure}

Technological innovations and solutions have increased automation trends in library and information systems resulting to expansion and delivery of quality services to the clients. Digital innovations and applications have enhanced service delivery through the Internet of Things systems, enterprise information management, cloud computing, radio frequency identification technology (RFID) and digital institutional repositories. Information organizations in international and national institutions have institutional repositories that provide and manage digital content. International webometrics rankings of academic and research institutions and related systems have promoted Kenyan universities with the University of Nairobi ranked among the top elite in Africa and Eastern and Central Africa (Webometrics Ranking, 2016). The digital repository of the University of Nairobi began in December 2012, and has since then grown tremendously in terms of projects, theses and dissertations; articles and papers; books and chapters; and conference proceedings. The University of Nairobi library system, information professionals and academicians, and researchers have made unparalleled and remarkable progress that puts the Kenyan knowledge society in the global digital economy.

The other indicator of the knowledge society that has been successfully integrated in mainstream library and information systems is the use of digital technological solutions that was initially the preserve of the business community. Many information centers have embraced technological solutions 
in order to stay on top of the digital business environment (Makori, 2012). In addition, government ministries, departments and agencies that were initially skeptical about open source systems have firmly embraced the digital solutions as witnessed in huduma center services. Library and information systems face numerous economic challenges due to limited financial resources, although many have fortunately found effective and free means of providing services through open source solutions. Many information centers have also adopted Koha system in addition to other open source software programmes.

\section{Innovation and Enterprise Programs}

Information organizations and information professionals across the world have implemented open access (OA) practices and initiatives where scholars are able to publish and share research results to the widest possible public, without barriers and restrictions. The open access movement emerged because of the hard financial situations compounded by ever increasing cost of scholarly and scientific journals that face information organizations and information professionals. In addition, the movement has transformed information organizations into business and economic hubs for income generation purposes. Pressure to share data comes from many stakeholders and interested parties - funding agencies (public and private), policy bodies (national academies and research councils, journal publishers, educators), and scholars and researchers (Borgman, 2012). The open access movement enhances democratization of availability and access to information that goes long way in bridging the knowledge gap between the developed and developing countries (Ezema, 2011).

The application of DSpace in creation of local content of projects and theses has fueled the open access movement and increased the research visibility of scholarly communication in academic institutions. Web and digital repositories have become the core resources for publishing quality academic and research papers and articles that reflect remarkable openness and excellence rankings globally for local content that were initially underutilized and untraceable (Makori, 2017). Information professionals and academicians in academic institutions have adopted innovative and business enterprise programs where clients pay for the services (binding of projects and theses) in addition to offering professional training programs. Emerging trends in electronic information have proved useful in bridging the knowledge gap and providing access to electronic journals and books, and research papers and articles. The electronic resources are widely used to support teaching, learning, research and community services in higher education.

\section{Development, Leadership and Management}

The knowledge economy is offering emerging challenges and opportunities necessitating the need for information professionals and academicians to rethink the best leadership and management skills to drive and propel business goals and objectives in organizations. Historically, leadership and management practices are as old as human civilization and have been evolving and developing in relation to best practices. From the traditional to knowledge society, humanity has always depended upon innovative leadership skills for socio-economic development and survival for the fittest. Leadership and management skills are one of the single biggest factors responsible for increased production and quality delivery of services to the customers in business and information organizations. Management is a combination of leadership, communication and people skills, where a manager without any leadership skills is like a ship sailing on high seas without use of compass and gyroscope (Ng, 2011). Sustainable leadership and management skills are fundamental in increasing opportunities and fixing organizational challenges that might hinder quality delivery of services to the customers. Information professionals and academicians have taken executive leadership and management responsibilities in universities and organizations. The professionals are also engaged in various African countries of South Africa, Zululand and Botswana.

Information professionals have also made positive contributions and empowered the society in solving societal problems. Nations across the globe exist and prosper based on freedom of information 
enshrined in the constitutional rights in line with best practices of democracy and governance. Governments also formulate policies that promote societal values and goals, develop human personnel and distribute resources for sustainable development. National government, county governments and the 2010 constitution have policies that guide development practices and the fight against poverty, diseases, ignorance and inequalities. Several information professionals have ventured into politics both at national government and county governments. In parliament and senate houses and county assemblies, information science professionals with the passion and synergy of servant leadership serve the citizens and the country. Information science political and opinion leaders, community experts, investigative journalists and lecturers are involved in socio-economic development programs. The famous "jicho pevu programme" is one such educative episodes that exposes among other issues corruption and unfair practices in the country. The program has in many occasions exposed corruption deals in government ministries, departments and agencies in addition to private organizations. Information professionals have made positive political developments that address economic disparities and inequities in rural and urban communities and among disadvantaged groups in the country.

\section{Information Governance, Ethics and Integrity}

Information governance, ethics and integrity influence knowledge, information and records management in organizations and institutions. The ANIE workshop on information ethics in Africa in 2011 noted that information ethics is a descriptive and emancipatory discipline dealing with the study of the changes in the relationship between people and the world due to information and communication technologies. Moreover, the workshop indicated that information ethics in Africa provides a unique platform that not only builds the information and knowledge society driven by critical reflection on ethos and values but also addresses opportunities and challenges unique to the continent. The concept is concerned with issues arising from the development and application of information technologies (Otike, 2010). Information communication technology solutions have been firmly grounded in modern business information centers, although the development has brought in new ethical and integrity issues. Such issues have been noted to have retrogressive effects in relation to the principles of freedom of information. In the knowledge economy, access and utilization of digital information content is defined and governed by the principles of privacy, accuracy, accountability, ownership and the right or privilege to obtain. Equally, information professionals have been vocal in addressing governance, ethics and integrity in international, regional and local conferences and seminars. The information ethics and integrity conference of 2014 was held in Uganda where the participants agreed on the need to form country chapters among other pertinent concerns. In the conference, Kenyan information professionals participated and presented papers on various topical issues on governance, ethics and integrity practices.

\section{RESEARCH METHODOLOGY}

\section{Research Design, Sampling Techniques and Collection Methods}

Quantitative and qualitative research methods where questionnaire and interview guides were used respectively in addition to literature scans and document review analyses to collect, summarize, present and interpret information. A closed ended questionnaire was used to obtain in-depth information on practical aspects of sustainable information development practices from 110 information professionals and academicians supported with interview guides. The respondents also provided information on the leading goals and strategies applied to achieve sustainable development practices against the challenges experienced in Kenya and around the world. Academic literature and document reviews drawn from reputable academicians, professionals, scholars and researchers also provided in-depth knowledge on sustainable information development practices. Information from websites, weblogs and social media interfaces of institutions and organizations were also used. Data and information 


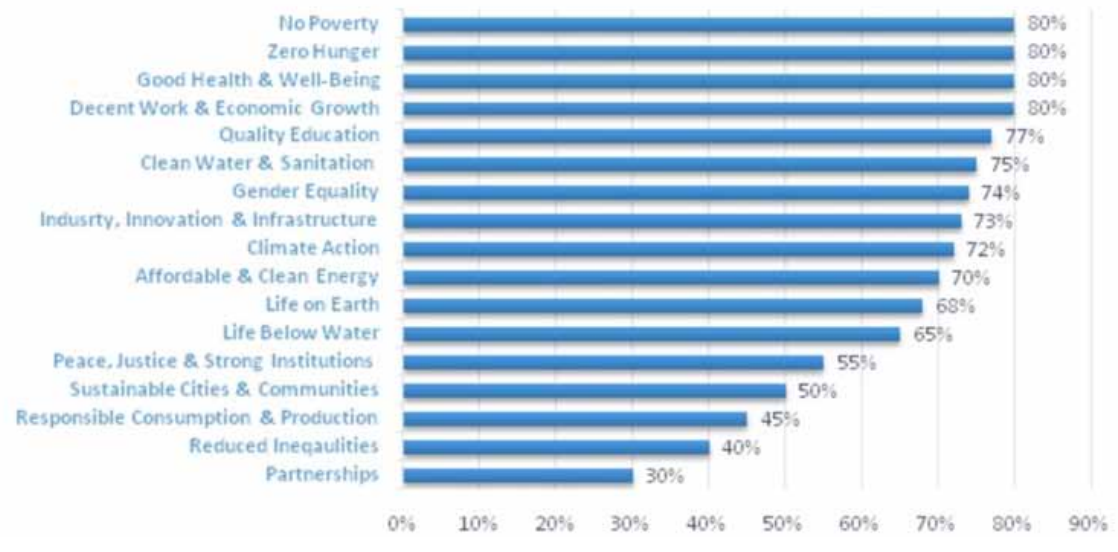

obtained through the various collection methods were reviewed, analyzed and organized into relevant themes and subthemes of the research.

\section{RESULTS AND DISCUSSION}

\section{Sustainable Information Development Practices}

The first objective examined relevant goals of sustainable information development practices applied in transforming societies. The purpose was to ascertain the leading sustainable development goals and practices important in offering new opportunities for economic growth and future prosperity. Respondents provided data and information on the nature of sustainable development goals where $98 \%$ reported of being aware and knowledgeable of the practices while $2 \%$ noted that the novel idea and strategy is still new and emerging. Notable sustainable development practices were ranked in order of priority, where 10 rudimentary goals with more than $70 \%$ were identified as being quite important in societal transformation, though this does not mean that the rest are not equally essential (Figure 2). The top quartile sustainable development goals were no poverty, zero hunger, good health and well-being as well as decent work and economic growth while reduced inequalities and partnerships took the bottom line. In the sustainable development goals matrix, decent work and economic growth is ranked position eight, appearing just below affordable and clean energy and above industry, innovation and infrastructure. From qualitative perspective, all the ten information science professionals unanimously noted that decent employment and economic growth provide not only sustainable income for better quality life and livelihoods but also forms the fundamental denominator to poverty eradication, adequate food, good health and well-being, quality education as well as clean water and sanitation. In Africa and other developing countries, employment and economic prosperity provide perfect opportunities that fight against poverty, hunger, diseases and ignorance. Information professionals have been involved in fundraising and mobilization activities to help the sick, support the poor and pay school fees through social media platforms, noted four knowledge managers.

During the agitation for independence, the primary responsibility was to fight the three enemies of development, namely poverty, diseases and ignorance. Poverty continues to remain elusive, although rapid progress and developments have been made and achieved in the economy. Wealth creation forms the fundamental basis of eradicating all forms of poverty and hunger normally witnessed in people, communities, societies and countries in the world. The fight against poverty and hunger is also achieved through jobs and employment opportunities that provide people with decent income and resources 


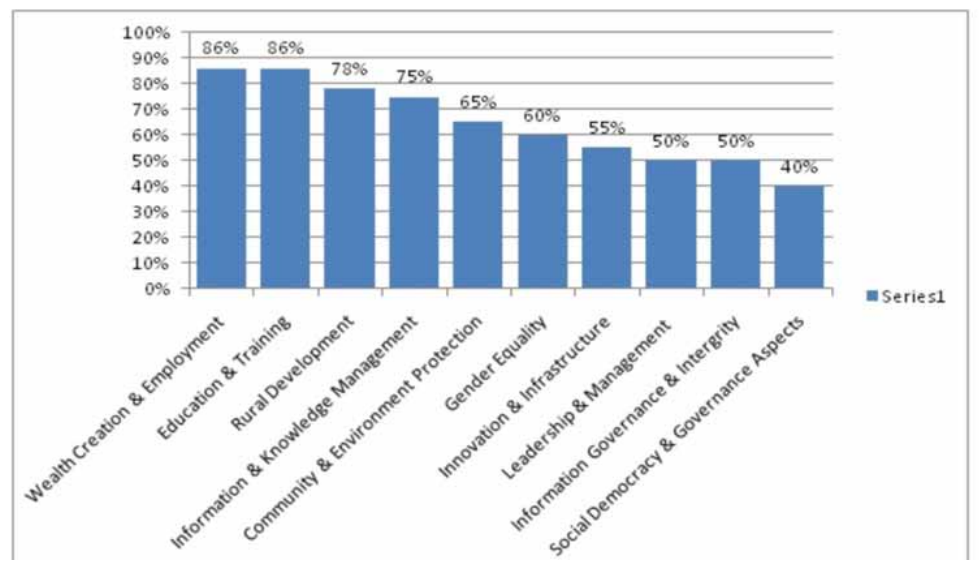

for development purpose. According to the affirmative action on gender equality, employment opportunities are fairly offered to all men and women with relevant qualifications, although there are cases where people with disabilities are given first priority as enacted in the constitution. Harmonization of salaries for all civil servants at national government, county governments and private organizations is being addressed so as to promote equal pay for work of equal value to all people. Information professionals are employed in multidimensional industries in public and private institutions, county governments, government ministries, departments and agencies, media houses and radio stations, and publishing organizations. Reducing poverty levels among the population is still a major challenge for the national government and county governments, although tremendous developments have been achieved.

\section{Practical Sustainable Development Practices}

The second objective determined practical sustainable development practices used in bringing societal transformation and change. In a multiple response question, the respondents identified practical sustainable development approaches applied in transforming and changing the life of people. Top priorities being wealth creation and employment opportunities as well as education and training followed with rural development while social democracy and governance aspects are the least (Figure 3). Information and knowledge management play strategic insights in sustainable development goals while quality education and training programs in academic and research institutions provide the other universal approach. Participation of information professionals in community services and environmental protection has proved useful in realizing the dreams of the global goals, opined five information managers. Leadership and management practices exhibited by information professionals in various sectors of the economy have helped to promote sustainable information goals and encourage political participation and activities, the information managers added.

The third objective demonstrated information methods applied in fostering environmental protection and sustainability. Respondents highlighted practical information methods, programs and initiatives widely used in sustaining climate and environmental protection as in Table 1. In the multiple response question, three-quarters of the respondents unanimously selected green building, green information policies and green information collection development methods. Approximately half of the respondents each reported green information communication technology and green information literacy skills with green community services taking a quarter. Most academic and research institutions have built greening learning resource centers for the digital natives complete with necessary green informational and technological requirements. Information schools, departments and academic libraries 
Table 1. Green Information Movement Methods

\begin{tabular}{|l|l|}
\hline \multicolumn{1}{|c|}{ Green Information Methods } & \multicolumn{1}{c|}{ Practical Programmes and Initiatives } \\
\hline Green Buildings & $\begin{array}{l}\text { Modern information centers, facilities, equipments, spacious, } \\
\text { discussion rooms, lighting, ventilation, heating and cooling. }\end{array}$ \\
\hline Green Information Policies & $\begin{array}{l}\text { Professional vision, mission and core values that support } \\
\text { goals and objectives. }\end{array}$ \\
\hline Green Information Collection Development & $\begin{array}{l}\text { Digital information resources and services, e-books and } \\
\text { journals, and e-procument. }\end{array}$ \\
\hline Green Information Communication Technology & $\begin{array}{l}\text { Information automation systems, cloud computing, RFID and } \\
\text { digital repositories. }\end{array}$ \\
\hline Green Information Literacy Skills & $\begin{array}{l}\text { Green knowledge and practices, information for decision } \\
\text { making and critical thinking. }\end{array}$ \\
\hline Green Community Services & $\begin{array}{l}\text { Protection of environment through participation - tree } \\
\text { planting and cleaning. }\end{array}$ \\
\hline
\end{tabular}

have visions, missions and core values well aligned with environmental protection and suitability practices both in words and actions. The ten information professionals collectively commented that nurturing the green information environment involves many small things that information professionals normally engage in. One such participation where information professionals have passionately participated and engaged is the tree planting sessions.

Electronic procurement and subscription of green digital information resources and green information communication technology (automation and digital repositories) are widely practiced in academic and research libraries. Information professionals and academicians teach information literacy skills and digital literacy skills. Libraries, by providing access to information and skills, help provide opportunities for people to improve own lives and support informed decision-making by governments, communities and others as well as provide services and support that reduce poverty and improve the prosperity of people everywhere (International Federation of Library Associations and Institutions, 2015). Most commonly used community based programs for protecting the environment are tree planting and cleaning activities.

Findings established the technological systems and solutions widely applied in utilization and sharing of information and knowledge for sustainable development practices. In entrenching technological values and digital economy, the majority of the respondents (90\%) identified social media interfaces especially Facebook, Twitter, LinkedIn and YouTube as the top innovation trends in information organizations for collaborative communication or peer-to-peer exchange. Similarly, $80 \%$ of the respondents noted that mobile apps, blogs and digital information systems (electronic resources - e-books and e-journals) are emerging as the digital assets for sustainable communication, information and knowledge. One university librarian asserted that mobile applications are widely applied in information and knowledge organizations for business transactions such as making payments for fines and bills. This has promoted information services and opportunities among the clients. Information communication technology is the driving force behind sustainable development goals and policies. Information professionals and academicians have embraced massive technological systems in research, teaching and community services. Advancing digital inclusion through access to information and communications technologies, supports sustainable development goals and practices, and libraries provide the information infrastructure to help people develop the capacity to use information effectively, and preserve information to ensure ongoing access for future generations (International Federation of Library Associations and Institutions, 2015). 


\section{Sustainable Strategies}

The fourth objective determined appropriate strategies for attaining sustainable information development policies and practices. Post-implementation frameworks to synchronise adequate flow of data, information, knowledge and technology for strategic planning and decision making is imperative for people, professionals, organizations and communities. Sustainable development practices depend upon well planned and executed strategies if the realistic process of transforming and changing the life of people is to be achieved, especially in African countries where infrastructures and economic policies are minimally provided due to poor social democracy and governance by the governments, and numerous challenges brought by inadequate human resources, poor information infrastructure, inadequate telecommunication systems, political instability, poor leadership and management skills, social and emotional problems as well as inability to accept change. In addition, post-implementation strategies provide the necessary guidelines useful in avoiding the pitfalls of the millennium development goals. In sustainable development, information, knowledge and technology are critical in promoting economic growth and eliminating ignorance, poverty and diseases. Postimplementation frameworks for sustainable development practices and strategies require inclusive elements of vision and mission policies, service delivery, quality leadership and management, participation and partnership, mobilization of resources, education and training, and disruptive technologies.

Strengthening sustainable development goals should link social, economic and political aspects of the people with appropriate solutions. Sustainable economic development and societal transformation entail the need for visionary and servant leadership and integrity to guide in regular formulation and implementation of practical goals and policies. This helps to develop vision and mission policies that are sustainable and inclusive in solving problems in the society. In African countries, rapid economic growth and prosperity is normally hindered by outdated policies and priorities that do not address adequately societal challenges of poverty, hunger, diseases, massive unemployment levels and inequalities. Fostering sustainable development practices is important if information science professionals are employable in the job market in addition to being innovative and creative in business and entrepreneurship activities to spur economic growth and prosperity while fighting poverty and diseases.

Participation and partnership from the public, professionals, organizations and communities including the ability of governments to provide adequate resources (humans and financial) is fundamental in sustainable social and economic transformation and empowerment. Education and training opportunities create well-informed societies where people acquire and share knowledge on many human aspects - socially, economically and politically. Indeed, increased financial investment and incentives in capacity building, education and training opportunities stimulate business and entrepreneurial synergies that strengths economic transformation and growth. In the modern knowledge age and digital economy, disruptive technologies are fundamental requirement that play central role in human development and economic transformation, suggested one information systems librarian. Technology is the business strategy and rudimentary element for anchoring human development and transformation in the society. Digital innovative systems and solutions require massive investment and financial resources. Strengthening sustainable development goals should involve investment in information communication technologies with the potential to provide innovative business solutions. Strategic insights should rethink the success of sustainable development in line with digital development and innovation trends, environmental change and social-economic challenges that confront humanity and society. 


\section{CONCLUSION}

- Sustainable development goals are not the panacea and preserve of any particular profession, discipline, individual and people, but collective responsibility and participation to promote socio-economic growth in the society. Centrality of the information discipline and profession in making the society better place for humans is vital in the fight against poverty, food insecurity, diseases and unemployment.

- The process of leveraging information and knowledge management in sustainable economy and safe environment is fundamental in societal transformation and change. Realistic prospect and purpose of sustainable development practices are based on people, information, knowledge and technology.

- Integration of sustainable development practices and strategies are fundamental issues that impact education and training of people and professionals, including information science. Economic transformation and change is possible through human capital development that provides people and the society with knowledge and skills for strategic planning and decision making.

\section{Recommendations}

- A modern sustainable economy should not depend upon employment opportunities alone but most importantly on innovation and creative information prospects. Strategies for sustainable development practices must integrate innovative information and knowledge policies to promote rapid economic growth and empowerment.

- Digital development and innovations are quite essential for a sustainable economy and their exclusion in human life can be disastrous. Information science academicians and professionals in the community and the society must participate in promotion of sustainable development practices and policies through inventions.

- There is need to improve and integrate sustainable development practices in economic, social and political aspects in order to provide secure societal values for future prosperity. Information and knowledge professionals play critical role in championing and implementing sustainable development policies and practices although there is need to carry out comprehensive and detailed assessment on the individual targets or pillars in transforming and changing the life of people in the society. 


\section{REFERENCES}

Aida, O. (2016). African Libraries and the Implementation of the SDGs: Public Institutions and Development Agents. UN Economic Commission for Africa.

Baruchson-Arbib, S. (2007). The Contribution of Information Science to the Social and Ethical Challenges of the Information Age. Journal of Information, Communication \& Ethics in Society, 5(2-3), 53-58. doi:10.1108/14779960710837560

Borgman, C. L. (2012). The Conundrum of Sharing Research Data. Journal of the American Society for Information Science and Technology, 63(6), 1059-1078. doi:10.1002/asi.22634

Commission for University Education. (2019). Universities in Kenya. Commission for Higher Education.

Constitution of Kenya. (2010). Government Printer.

Cornell University. (2010). Information Science. Author.

Dahlkild, N. (2011). The Emergence and Challenge of the Modern Library Building: Ideal Types, Model Libraries and Guidelines from the Enlightenment to the Experience Economy. Library Trends, 60(1), 11-42. doi:10.1353/lib.2011.0027

Dale, R. (2012). Development Planning: Concept and Tools for Planners, Managers and Facilitators. McGrawHall Book Company.

Dzidonu, C. (2010). An Analysis of the Role of ICTs to Achieving the MDGs: A Background Paper. Paper Commissioned by the Division for Public Administration and Development Management of the United Nations Department of Economic and Social Affairs.

Ezema, I. J. (2011). Building Open Access Institutional Repositories for Global Visibility of Nigerian Scholarly Publication. Library Review, 60(6), 473-483. doi:10.1108/00242531111147198

International Federation of Library Associations and Institutions. (2015). In Toolkit: Libraries and Implementation of the UN 2030 Agenda. Access and Opportunity for All: How Libraries Contribute to the United Nations 2030 Agenda. IFLA.

Jankowska, M. A. (2010). Practicing Sustainable Environmental Solutions: A Call for Green Policy in Academic Libraries. Against the Grain (Charleston, S.C.), 22(6), 12.

Jeffrey, D. S. (2012). From Millennium Development Goals to Sustainable Development Goals. Lancet, 379(9832), 2206-2211. doi:10.1016/S0140-6736(12)60685-0 PMID:22682467

Kamba, M. A. (2009). Access to Information: The Dilemma for Rural Community Development in Africa. Bayero University.

Keast, D. (2011). A Survey of Koha in Australian Special Libraries: Open Source Brings New Opportunities to the Outback. OCLC Systems \& Services: International Digital Library Perspectives, 27(1), 23-39. doi:10.1108/10650751111106537

Kevin, U., Nicholas, O., \& Ernest, A. (2014). Achieving Sustainable Development Goals Through Transformative Governance Practices and Vertical Alignment at the National and Sub-national Levels in Africa. Sharing Tools in Planning for Sustainable Development.

Makori, E. O. (2017). Promoting Innovation and Application of Internet of Things in Academic and Research Information Organizations. Library Review, 66(8-9), 655-678. doi:10.1108/LR-01-2017-0002

Makori, E. O. (2012). Bridging the Information Gap with the Patrons in University Libraries in Africa: The Case for Investments in Web 2.0 Systems. Library Review, 61(1), 30-40. doi:10.1108/00242531211207406

Makori, E. O., Odini, C., \& Ojiambo, J. (2013). Use of Information Communication Technologies in Education and Training of Undergraduate Library and Information Science Students in Two Selected Kenyan Universities. Library Review, 62(8-9), 585-601. doi:10.1108/LR-08-2012-0083

McGonigle, D \& Kathleen, M. (n.d.). Introduction to Information Science and Information Systems. Jones \& Bartlett Learning, LLC. 
Mohamedbhai, G. (2013). Transforming African Education for Graduate Employability. Bulletin, 179, 14-15.

Ng, L. C. (2011). Best Management Practices. Journal of Management Development, 30(1), 93-105. doi: $10.1108 / 02621711111098398$

Nolin, J. (2010). Sustainable Information and Information Science. Information Research, 15(2).

Otike, J. (2010). Teaching of Information Ethics in Kenya. Paper Delivered in a Conference on the Teaching of Information Ethics in Africa Held at the University of Botswana, Gaberone, Botswana.

Wartzman, R. (2014). What Peter Drucker Knew about 2020. Harvard Business Review.

Russell, A. W., Vanclay, F., \& Aslin, H. (2010). Technology Assessment in Social Context: The Case for a New Framework for Assessing and Shaping Technological Developments. Impact Assessment and Project Appraisal, 28(2), 109-116. doi:10.3152/146155110X498843

Serap, K., \& Joumana, B. (2014). From Green Libraries to Green Information Literacy. In Information Literacy Lifelong Learning and Digital Citizenship in the 21st Century. Springer International Publishing Switzerland.

Siobhan, D. (2014). The Path to Sustainable Development Includes Quality Education. Institute of Development Studies in the UK.

United Nations Development Programme. (2016). Sustainable Development Goals. Webometrics Ranking. Author.

William, A. (2013). Rethinking the Talloires Declaration. International Journal of Sustainability in Higher Education, 14(1), 56-70. doi:10.1108/14676371311288958 